\title{
ANALISIS PERTUMBUHAN PERUSAHAAN, STRUKTUR MODAL DAN KEBIJAKAN DIVIDEN TERHADAP NILAI PERUSAHAAN SEKTOR PROPERTI, REAL ESTATE DAN KONSTRUKSI BANGUNAN
}

\author{
Oleh : \\ Amna Mawardi \\ Sekolah Tinggi Ilmu Ekonomi DR KHEZ Muttaqien - Program Studi Manajemen \\ amnamawardi@gmail.com
}

\begin{tabular}{|c|c|}
\hline Article Info & Abstract \\
\hline $\begin{array}{l}\text { Article History : } \\
\text { Received } 23 \text { July - } 2020 \\
\text { Accepted } 20 \text { August - } 2020 \\
\text { Available Online } \\
\text { O7 Sept - } 2020\end{array}$ & $\begin{array}{l}\text { This study aims to analyze the effect of company growth, capital } \\
\text { structure, and dividend policy on firm value in property, real estate, } \\
\text { and building construction companies listed on the Indonesia Stock } \\
\text { Exchange for the period 2013-2017. The data used are secondary } \\
\text { data and the method used is panel data regression analysis with the } \\
\text { help of the Eviews } 9 \text { program to obtain a comprehensive picture of } \\
\text { the relationship between one variable with another variable. The } \\
\text { sample in this study consisted of } 19 \text { companies that were } \\
\text { consistently listed on the IDX for } 5 \text { years in the 2013-2017 period } \\
\text { with purposive sampling as a sampling method. The results of this } \\
\text { study are that the variable capital structure and dividend policy } \\
\text { have a significant influence on the firm's value partially at a level } \\
\text { of significance of less than 5\%. While the company's growth } \\
\text { variable does not have a significant effect on the company's value } \\
\text { partially. The results of the simultaneous regression analysis found } \\
\text { that company growth, capital structure, and dividend policy } \\
\text { together affect the value of the company. The predictive ability of } \\
\text { the three variables on firm value is } 72.1 \% \text { while the remaining } \\
27.9 \% \text { is influenced by other factors. }\end{array}$ \\
\hline
\end{tabular}

Keyword :

Company Growth, Capital

Structure, Dividend Policy,

Firm Value

\section{PENDAHULUAN}

Persaingan yang semakin ketat, telah membuat suatu perusahaan dituntut untuk meningkatkan kinerja keuangan perusahaan agar mampu bersaing dengan para kompetitornya guna mencapai tujuan jangka panjang diantaranya memberikan kemakmuran bagi pemegang saham dan memaksimalkan nilai perusahaan. Sektor Properti, Real Estate, dan Konstruksi Bangunan hingga saat ini masih menjadi salah satu sektor yang istimewa selama kurun waktu 5 tahun terakhir, dan diprediksi akan terus mengalami perkembangan di tahun kedepannya. Pada infrastuktur dan perumahan sesuai Program Janggka Menengah Nasional 2015-2019 akan dapat menjadikan indonesia menjadi tempat favorit di dunia untuk investasi saham properti. (www.presidenri.go.id, 2016). Performa yang baik menunjukan hasil yang dicapai perusahaan baik, pencapaian perusahaan yang baik menimbulkan persepsi pelaku pasar baik, dengan hal ini nilai perusahaan akan meningkat. Namun, pada kenyataannya harga saham sektor properti, real estate dan konstruksi bangunan cenderung fluktuatif.

Dari hasil analisis konsep yang berdasarkan dari tabel menunjukan bahwa sektor yang 
memiliki rata-rata harga saham tertinggi yaitu sektor Consumers Goods, sedangkan sektor Property, Real estate \& Buliding Construction merupakan sektor yang memiliki rata-rata saham paling rendah. Dimana harga saham suatu perusahaan dapat menggambarkan nilai suatu perusahaan, karena harga saham memiliki hubungan positif dengan nilai perusahaan. Husnan (2014) mengartikan nilai perusahaan sebagai harga yang mampu dibayarkan oleh calon pembeli ketika perusahaan tersebut dijual. Ketika suatu perusahaan telah terbuka atau telah menawarkan saham ke publik maka nilai perusahaan diartikan sebagai persepsi seorang investor terhadap perusahaan itu sendiri. Investor dapat mempergunakan nilai perusahaan sebagai dasar untuk melihat kinerja perusahaan pada periode mendatang, dimana nilai perusahaan sering dikaitkan dengan harga saham. Investor akan memperoleh keuntungan apabila harga saham perusahaan tinggi. Wijaya dan Panji (2015) menyatakan bahwa harga saham yang tinggi akan berbanding lurus dengan nilai perusahaan yang tinggi pula. Nilai perusahaan yang tinggi akan membuat rasa percaya seorang investor terhadap perusahaan meningkat (dalam I Nyoman dan I Ketut, 2017).

Perusahaan yang sudah go public dapat dikategorikan sebagai perusahaan besar atau perusahaan yang memiliki pertumbuhan baik, sehingga pertumbuhan perusahaan dapat mempengaruhi nilai perusahaan. Seorang investor akan lebih tertarik dengan perusahaan besar dibandingkan dengan perusahaan yang berukuran kecil. Pertumbuhan perusahaan dapat mencerminkan bahwa suatu perusahaan akan berkembang atau tidak. Struktur modal sangat penting bagi perusahaan karena akan berhubungan dan berpengaruh terhadap besarnya risiko yang ditanggung oleh pemegang saham dan besarnya tingkat pengembalian atau tingkat keuntungan yang diharapkan. Dengan kata lain, seandainya perusahaan mengganti modal sendiri dengan hutang, atau sebaliknya apakah harga saham akan mengalami perubahan atau tidak. Sehingga dengan struktur modal yang tepat, tujuan utama perusahaan untuk memaksimalkan nilai perusahaan dapat tercapai. Dengan demikian, manajer keuangan harus berhati-hati dalam menentukan proporsi pemenuhan dana tersebut.

Kebijakan dividen berpengaruh terhadap sikap para investor. Para pemegang saham akan memandang negatif terhadap perusahaan yang mengurangi dividen, karena mengurangi dividen dapat mereka kaitkan dengan kesulitan keuangan pada perusahaan tersebut. Selain itu, penurunan pembayaran dividen akan dilihat sebagai prospek perusahaan yang buruk dan pembayaran dividen yang besar akan dilihat sebagai prospek yang baik. Semakin cepat tingkat pertumbuhan suatu perusahaan, semakin besar kebutuhan dana untuk membiayai pertumbuhan perusahaan tersebut. Keputusan mengenai pemenuhan kebutuhan sumber dana untuk kegiatan operasional perusahaan merupakan hal yang sangat penting tentu dengan mempertimbangkan struktur modal yang optimum antara hutang dan modal sendiri. Dengan adanya perbedaan pendapat dari para ahli, mengenai bagaimana struktur modal atau penggunaan hutang terhadap nilai perusahaan juga dapat di pertimbangkan melalui kebijakan dividen. Di mana kebijakan dividen yang digunakan oleh suatu perusahaan tentu dapat mempengaruhi kepuasan dan kepercayaan investor dan tentunya akan memengaruhi nilai dari perusahaan tersebut.

\section{KAJIAN PUSTAKA PEGEMBANGAN HIPOTESIS Nilai Perusahaan}

Brigham dan Houston (2006) dalam Syarinah (2017) menyatakan bahwa, nilai perusahaan merupakan nilai yang dapat ditentukan oleh pembagian hasil sebagai kinerja perusahaan, nilai perusahaan dilihat dari maksimalisasi kekayaan pemegang saham yang dimaksudkan ke dalam memaksimumkan harga saham perusahaan. Seperti yang dikemukakan oleh Brigham dan Houston (2006) di atas, dalam meningkatkan nilai perusahaan hal yang dapat dilakukan oleh manajemen yaitu dengan memakmurkan para pemilik dan pemegang saham. Nilai perusahaan dapat tercermin melalui harga saham, bagi perusahaan yang menerbitkan sahamnya di pasar modal. Semakin tinggi harga saham 
berarti semakin tinggi pula tingkat pengembalian kepada para investor serta nilai perusahaan pun akan meningkat. Dalam perusahaan yang menerbitkan saham, umumnya nilai perusahaan diproksi oleh Price to Book Value (PBV). Rumus untuk menghitung PBV adalah :

$$
\mathrm{PBV}=\frac{\text { harga per lembar saham }}{\text { nilai buku per lembar saham }}
$$

\section{Pertumbuhan Perusahaan}

Kusumajaya (2011) berpendapat bahwa pertumbuhan (growth) adalah peningkatan ataupun penurunan dari total aset yang dimiliki perusahaan. Aset suatu perusahaan merupakan aktiva yang digunakan untuk kegiatan operasoinal perusahaan, hal tersebut diharapkan dapat meningkatkan hasil operasional perusahaan sehingga semakin menambah kepercayaan pihak luar. Selain itu, pertumbuhan perusahaan dapat memberikan sinyal positif yang diharapkan oleh pihak dalam maupun luar perusahaan (dalam I Nyoman dan I Ketut, 2017). Growth (pertumbuhan perusahaan) dihitung menggunakan perubahan total aset perusahaan sebagai berikut (Kusumajaya, 2011):

Growth $=\frac{\text { Total Aktivat }- \text { Total Aktivat }-1}{\text { Total Aktivat }-1} \times 100 \%$

\section{Struktur Modal}

Bambang Riyanto (2010) mengemukakan bahwa, struktur modal merupakan perbandingan antara hutang jangka panjang dengan modal sendiri. Pendanaan perusahaan berasal dari dua sumber yaitu sumber intern dan sumber ekstern. Baik buruknya struktur modal akan mempunyai efek yang langsung terhadap posisi keuangan perusahaan. Suatu perusahaan yang memiliki struktur modal yang tidak baik, di mana mempunyai utang yang begitu besar akan memberikan beban berat kepada perusahaan yang bersangkutan (Riyanto, 2010). Pengukuran struktur modal dalam penelitian ini menggunakan Long Term Debt to Equity Ratio (LTDER). LTDER merupakan perbandingan antara hutang jangka panjang dengan modal sendiri (Sudana, 2011). Dengan rumus sebagai berikut:

$$
\text { LTDER }=\frac{\text { Long Term Debt }}{\text { Total Equity }}
$$

\section{Kebijakan Dividen}

Menurut Sartono (2010) dalam Rara dan Susanto (2018), menyatakan bahwa, kebijakan dividen adalah keputusan apakah laba yang diperoleh perusahaan akan dibagikan kepada pemegang saham sebagai dividen atau akan ditahan guna pembiayaan investasi di masa yang akan datang. Kebijakan dividen diukur dengan menggunakan Dividen Payout Ratio (DPR). Dimana Dividen Payout Ratio (DPR) membandingkan antara dividen per lembar saham dengan laba per saham. Satuan dalam DPR adalah persentase. DPR dapat dirumuskan sebagai berikut: (Wiagustini, 2010 dalam Ni Kadek dan I Gede, 2016). $D P R=\frac{\text { dividend per share }}{\text { earning per share }} \times 100 \%$

\section{METODE PENELITIAN}

Metode penelitian yang digunakan dalam penelitian ini adalah metode pendekatan kuantitatif. Jenis data yang digunakan adalah data sekunder dan merupakan data cross section dan time series. Data yang digunakan berupa laporan keuangan perusahaan properti, real estate dan konstruksi bangunan yang terdaftar di BEI periode 2013-2017. Metode penarikan sampel menggunakan metode purposive sampling. Teknis analisis data yang digunakan adalah analisis regresi data panel yang diolah melalui aplikasi Eviews 9.

\section{HASIL DAN PEMBAHASAN}

Pada penelitian ini, analisis pertama yang dilakukan adalah analisis deskriptif. Berikut ini merupakan tabel mengenai deskripsi data dari tiap variabel yang digunakan dalam penelitian ini.

Tabel 1 Statistik Deskriptif

\begin{tabular}{lcccc}
\hline \hline & $\mathrm{Y}$ & $\mathrm{X} 1$ & $\mathrm{X} 2$ & $\mathrm{X} 3$ \\
\hline \hline Mean & 2.415419 & 0.212541 & 0.536642 & 0.301451 \\
Median & 1.673342 & 0.146905 & 0.423172 & 0.190476 \\
Maximum & 12.76962 & 1.416601 & 4.102171 & 3.721541 \\
Minimum & 0.377153 & -0.164181 & 0.067343 & 0.019559 \\
Std. Dev. & 2.012040 & 0.224815 & 0.517458 & 0.464887 \\
Skewness & 2.268093 & 2.486212 & 4.476633 & 5.293576 \\
Kurtosis & 9.793356 & 11.95805 & 28.82077 & 35.85590 \\
& & & & \\
Jarque-Bera & 264.1264 & 415.5130 & 2956.373 & 4716.743 \\
Probability & 0.000000 & 0.000000 & 0.000000 & 0.000000 \\
& & & & \\
Sum & 229.4648 & 20.19137 & 50.98101 & 28.63787 \\
Sum Sq. Dev. & 380.5405 & 4.750936 & 25.16969 & 20.31528 \\
& & & & \\
Observations & 95 & 95 & 95 & 95 \\
\hline Sumber: Output Eviews & 9,2019 & &
\end{tabular}


Analisis selanjutnya yaitu menentukan estimasi model regresi data panel terbaik untuk dilakukan pengujian pada hipotesis. Sebelumnya penulis telah melakukan pengujian tiga model estimasi data panel yaitu common effect model, fixed effect model, dan random effect model. Untuk melakukan perbandingan model mana yang paling cocok digunakan pada penelitian ini, maka penulis juga telah melakukan uji pemilihan model, yaitu uji $\mathrm{F}$ test (Chow test) untuk memilih antara model common effect dan fixed effect model. jika hasilnya adalah terima hipotesis nol yaitu model terbaik adalah common effect, maka tidak perlu dilakukan uji lanjutan yaitu Uji Hausman test. Ttapi apabila hasilnya menolak hipotesis nol, maka model terbaik yang terpilih adalah fixed effect model maka perlu dilakukana uji lanjutan yaitu uji hausman test. Hasil dari Uji Chow test dapat dilihat pada tabel di bawah ini:

\section{Tabel 2 Hasil Uji Chow}

Redundant Fixed Effects Tests

Equation: Untitled

Test cross-section fixed effects

\begin{tabular}{lrrr}
\hline \hline Effects Test & Statistic & d.f. & Prob. \\
\hline \hline $\begin{array}{l}\text { Cross-section F } \\
\begin{array}{l}\text { Cross-section } \\
\text { Chi-square }\end{array}\end{array}$ & 7.750844 & $(18,73)$ & 0.0000 \\
\hline \hline
\end{tabular}

Sumber: Output Eviews 9, 2019

Dari hasil tersebut menunjukkan nilai $\mathrm{F}$ statistik sebesar 7.750844 dengan nilai $p$ value $0.0000<\alpha 0,05$, sedangkan nilai chisquare sebesar 101.512631 dengan nilai $\mathrm{p}$ value $0.0000<\alpha 0,05$. Maka nilai signifikan tersebut menunjukkan bahwa model yang dipilih adalah fixed effect model dengan catatan lebih signifikan dibandingkan dengan common effect model. Hasil dari Uji Hausman test dapat dilihat pada tabel di bawah:
Tabel 3 Hasil Uji Hausman

Correlated Random Effects - Hausman

Test

Equation: Untitled

Test cross-section random effects

\begin{tabular}{lrrr}
\hline \hline & $\begin{array}{r}\text { Chi-Sq. } \\
\text { Statistic }\end{array}$ & $\begin{array}{r}\text { Chi-Sq. } \\
\text { d.f. }\end{array}$ & Prob. \\
\hline \hline $\begin{array}{l}\text { Cross-section } \\
\text { random }\end{array}$ & 27.085014 & 3 & 0.0000 \\
\hline \hline
\end{tabular}

Sumber: Output Eviews 9, 2019

Dari hasil tersebut menunjukkan bahwa nilai prob. value $0,0000<\alpha 0,0500$ (5 persen). Maka dapat disimpulkan bahwa model fixed effect lebih baik dibandingkan dengan model random effect. Pada penelitian ini tidak semua uji asumsi klasik dilakukan karena menggunakan data panel. Uji asumsi klasik yang dilakukuan adalah uji normalitas, uji multikolinearitas dan uji heteroskedastisitas. Di bawah ini adalah tabel hasil pengujian uji asumsi klasik yang telah dilakukan:

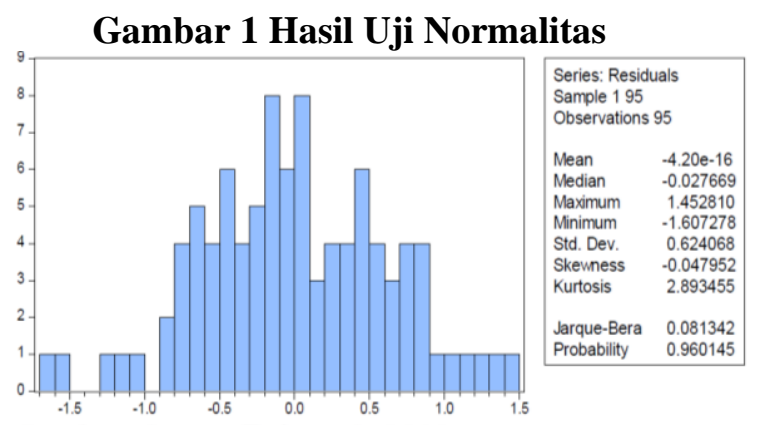

Sumber: Output Eviews 9, 2019

Interpretasi hasil dari gambar 1 dapat dilihat bahwa hasil Probabilitas Jarque-Bera sebesar $0.960>0.05$, maka data tersebut terdistribusi normal yang berarti pengujian asumsi klasik dalam model regresi data panel telah memenuhi asumsi normalitas.

Tabel 4 Hasil Uji Multiklolinearitas

\begin{tabular}{cccc} 
& $\mathrm{X} 1$ & $\mathrm{X} 2$ & $\mathrm{X} 3$ \\
\hline \hline $\mathrm{X} 1$ & 1.000000 & 0.022244 & -0.185554 \\
$\mathrm{X} 2$ & 0.022244 & 1.000000 & 0.254813 \\
$\mathrm{X} 3$ & -0.185554 & 0.254813 & 1.000000 \\
\hline \multicolumn{2}{l}{ Sumber: Output Eviwes 9,2019 }
\end{tabular}

Berdasarkan tabel di atas dapat dilihat bahwa masing-masing variabel mempunyai nilai koefisien < 0,85 maka dapat disimpulkan bahwa model regresi tidak mengalami masalah multikolinearitas. 
Tabel 5 Hasil Uji Heteroskedastisitas

Heteroskedasticity Test: White

\begin{tabular}{lclc}
\hline \hline $\begin{array}{l}\text { F-statistic } \\
\text { Obs*R- } \\
\text { squared }\end{array}$ & 1.231610 & $\begin{array}{l}\text { Prob. F(9,85) } \\
\text { Prob. Chi- }\end{array}$ & 0.2869 \\
$\begin{array}{l}\text { Scaled } \\
\text { explained SS }\end{array}$ & 10.95938 & $\begin{array}{l}\text { Square(9) } \\
\text { Prob. Chi- } \\
\text { Square(9) }\end{array}$ & 0.2785 \\
\hline \hline
\end{tabular}

Sumber: Output Eviews 9, 2019

Berdasarkan tabel 5 diperoleh hasil berupa nilai probabilitas Chi-Square sebesar 0,3907. Nilai probabilitas Chi- Square lebih besar dari taraf signifikansi $(0,3907>0,05)$ sehingga dapat disimpulkan model regresi tidak ada heteroskedastisitas atau sudah bersifat homogen. Pengujian hipotesis pada penelitian ini diuji dengan fixed effect model pada aplikasi Eviews 9. Berikut ini hasil adalah dari pengujian hipotesis menggunakan fixed effect model.

\section{Tabel 6 Hasil Estimasi Model Regresi}

\begin{tabular}{|c|c|c|c|c|}
\hline Variable & Coefficient & Std. Error & t-Statistic & Prob. \\
\hline $\mathrm{C}$ & 1.891804 & 0.323815 & 5.842237 & 0.0000 \\
\hline $\mathrm{X} 1$ & 0.174052 & 0.795584 & 0.218772 & 0.8274 \\
\hline $\mathrm{X} 2$ & 1.093205 & 0.148900 & 7.133290 & 0.0003 \\
\hline $\mathrm{X} 3$ & 1.665571 & 0.073902 & 9.006075 & 0.0000 \\
\hline \multicolumn{5}{|c|}{ Effects Specification } \\
\hline \multicolumn{5}{|c|}{ Cross-section fixed (dummy variables) } \\
\hline & \multicolumn{4}{|c|}{ Mean dependent } \\
\hline R-squared & 0.721487 & \multirow{2}{*}{\multicolumn{2}{|c|}{ Var }} & \multirow[t]{2}{*}{2.415419} \\
\hline Adjusted R- & & & & \\
\hline $\begin{array}{l}\text { squared } \\
\text { S.E. of }\end{array}$ & 0.641367 & \multicolumn{2}{|c|}{$\begin{array}{l}\text { S.D. dependent var } \\
\text { Akaike info }\end{array}$} & 2.012040 \\
\hline regression & 1.204929 & \multirow{2}{*}{\multicolumn{2}{|c|}{ Criterion }} & 3.410459 \\
\hline Sum squared & & & & \multirow{2}{*}{4.001884} \\
\hline $\begin{array}{l}\text { resid } \\
\text { Log }\end{array}$ & 105.9854 & \multicolumn{2}{|c|}{$\begin{array}{l}\text { Schwarz criterion } \\
\text { Hannan-Quinn }\end{array}$} & \\
\hline likelihood & \multicolumn{3}{|c|}{-139.9968 criter. } & 3.649439 \\
\hline F-statistic & 9.005069 & \multirow{2}{*}{\multicolumn{2}{|c|}{ Stat }} & \multirow[t]{2}{*}{1.890161} \\
\hline statistic) & 0.000000 & & & \\
\hline
\end{tabular}

Sumber: Output Eviews 9, 2019

Berdasarkan Tabel 6 maka dapat dibuat model persamaan analisis regresi sebagai berikut : Yit $=1,891804+0,174052(\mathrm{X} 1) \mathrm{it}+$ 1,093205(X2)it + 1,665571(X3)it + eit

Koefisien regresi variabel Pertumbuhan Perusahaan adalah sebesar 0,174052 . Artinya jika variabel independen lain nilainya tetap dan nilai dari pertumbuhan perusahaan mengalami kenaikan 1 poin, maka nilai dari Nilai Perusahaan akan mengalami kenaikan sebesar 0,174052 poin. Begitupula sebaliknya, jika variabel independen lain nilainya tetap dan nilai dari Pertumbuhan Perusahaan mengalami penurunan sebesar 0,174052 poin. Dalam hal ini pengaruh dari variabel independen Pertumbuhan Perusahaan adalah berbanding lurus dengan Nilai Perusahaan, artinya semakin meningkat Pertumbuhan Perusahaan maka nilai dari Nilai Perusahaan juga akan semakin meningkat, begitu pula sebaliknya.

Koefisien regresi variabel Struktur Modal adalah sebesar 1,093205. Artinya jika variabel independen lain nilainya tetap dan nilai dari struktur modal mengalami kenaikan 1 poin, maka nilai dari Nilai Perusahaan akan mengalami kenaikan sebesar 1,093205 poin. Begitupula sebaliknya, jika variabel independen lain nilainya tetap dan nilai dari struktur modal mengalami penurunan sebesar 1,093205 poin. Dalam hal ini pengaruh dari variabel independen Struktur Modal adalah berbanding lurus dengan Nilai Perusahaan, artinya semakin meningkat Struktur Modal maka nilai dari Nilai Perusahaan juga akan semakin meningkat, begitu pula sebaliknya. Koefisien regresi variabel Kebijakan Dividen adalah sebesar 1,665571 . Artinya jika variabel independen lain nilainya tetap dan nilai dari Kebijakan Dividen mengalami kenaikan 1 poin, maka nilai dari Nilai Perusahaan akan mengalami kenaikan sebesar 1,665571 poin. Begitupula sebaliknya, jika variabel independen lain nilaniya tetap dan nilai dari kebijakan dividen mengalami penurunan sebesar 1,665571 poin. Dalam hal ini pengaruh dari variabel independen Kebijakan Dividen adalah berbanding lurus dengan Nilai Perusahaan, artinya semakin meningkat Kebijakan Dividen maka nilai dari Nilai Perusahaan juga akan semakin meningkat, begitu pula sebaliknya.

\section{Hasil Pengujian Hipotesis Pertama}

Berdasarkan Uji $\mathrm{t}$ yang telah dilakukan diketahui nilai $t$ hitung untuk variabel Pertumbuhan Perusahaan adalah sebesar $0,218772<\mathrm{t}$ tabel 1,986 dengan nilai probvalue (sig) $0,8274>0,05$, sehingga dapat disimpulkan bahwa $\mathrm{H} 0$ diterima dan $\mathrm{H} 1$ ditolak, artinya tidak ada pengaruh antara Pertumbuhan Perusahaan terhadap Nilai Perusahaan pada perusahaan properti, real esatate dan konstruksi bangunan yang terdaftar di Bursa Efek Indonesia selama periode 2013-2017. Sejalan 
dengan penelitian terdahulu yang dilakukan I Nyoman dan I Ketut (2017) bahwa pertumbuhan perusahaan memilki hubungan negatif terhadap nilai perusahaan pada perusahaan Properti di BEI tahun 2013-2015.

Berdasarkan hasil penelitian memiliki arti bahwa pertumbuhan perusahaan tidak mendorong perubahan tingkat nilai perusahaan pada perusahaan sektor properti, real estate, dan konstruksi bangunan periode 2013-2017. Jika dilihat dari hasil perhitungan rasio Growth, ratarata Growth perusahaan properti, real estate, dan konstruksi bangunan selama 5 tahun tidak mengalami pertumbuhan yang baik. Hal ini disebabakan oleh beberapa faktor, yaitu faktor internal, eksternal, dan pengaruh iklim industri lokal. Faktor esksternal meliputi, pertumbuhan ekonomi yang tidak stabil, pendapatan perkapita yang stagnan, sehingga Indeks Keyakinan Konsumen (IKK) mengalami penurunan yang pada akhirnya harga saham perusahaan menurun serta tidak dapat meningkatkan nilai perusahaan.

\section{Hasil Pengujian Hipotesis Kedua}

Berdasarkan Uji $t$ yang telah dilakukan diketahui nilai t hitung untuk variabel Struktur Modal adalah sebesar 7,133290 > t tabel 1,986 dengan nilai prob-value (sig) $0,0003<0,05$, sehingga dapat disimpulkan bahwa $\mathrm{H} 0$ ditolak H2 diterima, artinya Struktur Modal memiliki pengaruh positif dan signifikan terhadap Nilai Perusahaan pada perusahaan sektor properti, real esatate dan konstruksi bangunan yang terdaftar di Bursa Efek Indonesia selama periode 2013-2017. Hasil penelitian ini sesuai dengan penelitian yang dilakukan oleh Diana dan Devi (2018) bahwa struktur modal yang diukur oleh Long Term Debt to Equity Ratio (LTDER) berpengaruh positif dan signifikan terhadap nilai perusahaan pada perusahaan Sub Sektor Makanan Dan Minuman Yang Terdaftar Di Bursa Efek Indonesia Tahun 2013-2016.

Berdasarkan hasil penelitian tersebut menunjukkan bahwa semakin tinggi nilai struktur modal maka nilai perusahaan juga akan semakin meningkat. Hasil ini sejalan dengan teori yang dikemukakan oleh Modigliani dan Miller (1963) dalam Husnan (2006) yang mengungkapkan bahwa apabila persusahaan dikenakan pajak penghasilan maka penggunaan hutang merupakan keputusan yang tepat diambil oleh perusahaan untuk meningkatkan nilai perusahaan.
Hasil penelitian yang dilakukan diketahui bahwa sturktur modal berpengaruh secara nyata terhadap nilai perusahaan, artinya tingginya rasio utang jangka panjang terhadap ekuitas berimplikasi pada meningkatnya nilai perusahaan. Jika dilihat dari hasil perhitungan Long Term Debt to Equity Ratio (LTDER) pada perusahaan sektor properti, real esatate dan konstruksi bangunan yang terdaftar di Bursa Efek Indonesia, perusahaan lebih banyak mengunakan struktur modal dari sisi utang jangka panjang.

\section{Hasil Pengujian Hipotesis Ketiga}

Berdasarkan Uji $\mathrm{t}$ yang telah dilakukan diketahui nilai $t$ hitung untuk variabel Kebijakan Dividen adalah sebesar 9,006075 > t tabel 1,986 dengan nilai signifikansi $0,0000<$ 0,05 , sehingga dapat disimpulkan bahwa H0 ditolak dan H3 diterima, artinya Kebijakan Dividen memiliki pengaruh positif dan signifikan terhadap Nilai Perusahaan pada perusahaan properti, real esatate dan konstruksi bangunan yang terdaftar di Bursa Efek Indonesia selama periode 2013-2017.

Hasil penelitian ini konsisten dengan penelitian yang dilakukan oleh Ni Kadek (2017) bahwa kebijakan dividen memiliki pengaruh positif dan signifikan terhadap nilai perusahaan pada perusahaan Manufaktur di BEI periode 20112013. Hasil pengolahan data juga sejalan dengan teori "Bird in The Hand Theory" yang menyatakan bahwa pemegang saham lebih menyukai dividen yang tinggi karena memiliki kepastian yang tinggi dibandingkan dengan capital gain dan investor memandang bahwa dividen adalah yang terbaik. Karena investor lebih suka kepastian tentang return investasinya serta mengantisipasi risiko ketidakpastian tentang kebangkrutan perusahaan.

Tabel 7 Hasil Perhitungan Koefisien Determinasi

R-squared 0.721487

Adjusted R-squared 0.641367

Sumber: Output Eviews 9, 2019

Dari tabel di atas diperoleh koefisien determinasi atau R Square adalah 0.721487 . Hasil perhitungan tersebut menunjukan bahwa pengaruh variabel pertumbuhan perusahaan, struktur modal, dan kebijakan dividen terhadap nilai perusahaan secara simultan adalah 0,721 
atau 72,1 \% dan sisanya sebesar 27,9\% dipengaruhi variabel lain.

\section{KESIMPULAN}

Berdasarkan analisis data, pengujian hipotesis dan pembahasan penelitian yang dilakukan pada perusahaan sektor Properti, Real Estate dan Konstruksi Bangunan di Bursa Efek Indonesia periode 2013 - 2017, maka dapat disimpulkan sebagai berikut:

a. Pertumbuhan perusahaan yang diukur menggunakan rasio Growth tidak berpengaruh terhadap nilai perusahaan pada perusahaan sektor Properti, Real Estate, dan Konstruksi Bangunan di Bursa Efek Indonesia periode 2013 2017. Artinya, pertumbuhan perusahaan tidak mendorong perubahan tingkat nilai perusahaan pada perusahaan sektor Properti, Real Estate dan Konstruksi Bangunan di Bursa Efek Indonesia periode 2013 2017.

b. Struktur Modal yang diukur menggunakan Long Term Debt To Equity Ratio (LTDER) memiliki pengaruh secara nyata terhadap nilai perusahaaan pada perusahaan sektor Properti, Real Estate dan Konstruksi Bangunan di Bursa Efek Indonesia periode 2013 - 2017. Artinya, semakin tinggi nilai struktur modal maka nilai perusahaan juga akan semakin meningkat. Penggunaan hutang dapat meningkatkan penilaian pasar yang berdampak pada penawaran harga saham di pasar modal semakin meningkat, dan sebagai sinyal yang diberikan perusahaan kepada investor sehingga nilai perusahaan mengalami peningkatan.

c. Kebijakan Dividen yang diukur menggunakan Dividend Payout Ratio (DPR) memiliki pengaruh secara nyata terhadap nilai perusahaan pada perusahaan sektor Properti, Real Estate dan Konstruksi Bangunan di Bursa Efek Indonesia periode 2013 - 2017. Artinya, semakin tinggi nilai kebijakan dividen maka nilai perusahaan juga akan semakin meningkat. Tingginya rasio dividen per lembar saham terhadap laba per saham berimplikasi pada tingkat perubahan nilai perusahaan. Karena pembayaran dividen yang tinggi merupakan signal positif yang menyatakan prospek perusahaan semakin baik sehingga investor semakin tertarik untuk membeli saham dan nilai perusahaan akan meningkat.

d. Secara bersama-sama (simultan), ketiga variabel Pertumbuhan Perusahaan, Struktur Modal, dan Kebijakan Dividen berpengaruh secara nyata terhadap Nilai Perusahaan pada perusahaan sektor Properti, Real Estate dan Konstruksi Bangunan di Bursa Efek Indonesia periode 2013 - 2017.

\section{REFERENSI}

Arikunto, S. 2010. Prosedur Penelitian Suatu Pendekatan Praktik. Jakarta: PT Rineka Cipta.

Anggriawan, Ferry, dkk. 2017. Pengaruh Struktur Modal Terhadap Nilai Perushaaan pada Perusahaan Sub Sektor Makanan dan Minuman yan Listing di Bursa Efek Indonesian Tahun 20112015. Jurnal Administrasi Bisnis Vol. 50 No 4 September 2017. Universitas Brawijaya.

Apsari, Idha Ayu. 2015. Pengaruh Return On Equity, Net Profit Margin, Debt To Equity Ratio Dan Longterm Debt Equity Ratio Terhadap Price Book Value. Jurnal Administrasi Bisnis. Volume. 27 No. 2. Oktober 2015. Universitas Brawijaya, 18.

Basuki, A. T., \& Purwanto, N. 2016. Analisis Rgersi Dalam Penelitian Ekonomi \& Bisnis. Jakarta: Rajawali Pers.

Diana Permatasari dan Devi Farah Azizah. 2018. Pengaruh Struktur Modal Terhadap Nilai Perusahaan (Studi Pada Perusahaan Sub Sektor Makanan Dan Minuman Yang Terdaftar Di Bursa Efek Indonesia Tahun 2013-2016). Jurnal Administrasi Bisnis (JAB). Vol. 61 No. 4 Agustus 2018

Dewi, Amalia. et. al. 2015. Pengaruh Ukuran Perusahaan, Profitabilitas, Struktur Modal, dan Keputusan Investasi Terhadap Nilai Perusahaan Pada Perusahaan Sektor Properti, Real Estate, dan Buliding Construction Yang Terdaftar di Bursa Efek Inodenia (BEI) 
Periode 2010-2013. Jurnal Administrasi Bisnis (JAB) Vol. 23 No. 2 Juni 2015.

Eugene F. Brigham and Joel F. Houston, 2011. Dasar - Dasar Manajemen Keuangan Buku 2. Edisi sebelas. Jakarta: Salemba Empat.

Ghozali, Imam. 2011. Aplikasi Analisis Multivariate dengan Program IBM SPSS 19. Semarang : Badan Penerbit Universitas Diponegoro.

Ghozali, Imam. 2014. Ekonometrika Teori, Konsep dan Aplikasi dengan IBM SPSS 22. Semarang : Badan Penerbit Universitas Diponegoro.

Isabella Permata Dhani dan A.A Gde Satia Utama. 2017. Pengaruh Pertumbuhan Perusahaan, Struktur Modal, dan Profitabilitas Terhadao Nilai Perusahaan pada Perusahaan Manufaktur Sektor Industri Barang Konsumsi yang Terdaftar di Bursa Efek Indonesia Tahun 2013-2015. Jurnal Riset Akuntansi dan Bisnis FEB Universitas Airlangga Vol. 2, No.1, (2017) 135-148 ISSN: 2548-1410.

I Nyoman Agus Suwardika dan I Ketut Mustanda. 2017. Pengaruh Leverage, Ukuran Perusahaan, Pertumbuhan Perusahaan dan Profitabilitas Terhadap Nilai Perusahaan pada Perusahaan Properti yang Terdaftar di Bursa Efek Indonesia Tahun 2013-2015.E-Jurnal Manajemen Unud, Vol. 6, No. 3, 2017: 1248- 122 ISSN: 2302-8912. Fakultas Ekonomi dan Bisnis Universitas Udayana Bali.

Lisma, Juliani. 2019. Analisa Kredit Modal Kerja Dan Kredit Investasi Sektor Industri Kecil Dan Menengah (Studi Kasus Pada PT. IKS Sebagai Debitur Bank BRI). Jurnal Ekonomi dan Bisnis, Vol. 6 No. 1 Februari 2019. ISSN: 25034413. Prodi Akuntansi STIE DR. Khez Muttaqien Purwakarta.

Munawar, Nandang. 2013. Pengaruh Posisi Kas, Current Ratio. Debt To Equity Atio dan Gross Profit Ratio Terhadap Return Saham Pada Perusahaan Yang Terdaftar Dalam Jakarta Islamic Index Bursa Efek Indonesia 2004-2007. Jurnal Ekonomi dan Bisnis, Edisi 1 No. 1 Juli 2012. ISSN: 2252-4495. Prodi Akuntansi STIE DR. Khez Muttaqien Purwakarta.

Nanang Ari Utomo dan Nisa Novia Avien Chirsty. 2017. Pengaruh Struktur Modal,
Profitabilitas, dan Ukuran Perusahaan Terhadap Nilai Perusahaan pada Perusahaan LQ45 di Bursa Efek Indonesia Periode 2012-2015. Jurnal Bingkai Manajemen (BiMA) Fakultas Ekonomi Universitas Semarang.

Nelly Agustina Musabbihan dan Ni Ketut Purnawati. 2018. Pengaruh Profitabilitas dan Kebijakan Dividen Terhadap Nilai Perusahaan Dengan Struktur Modal Sebagai Pemediasi. E-Jurnal Manajemen Unud, Vol. 7, No. 4 2018: 1979-2009. Fakultas Ekonomi dan Bisnis Universitas Udayana.

Ni Kadek Rai Prastuti dan I Gede Merta Sudhiarta. 2016. Pengaruh Sturktur Modal, Kebijakan Dividen dan Ukuran Perusahaan Terhadap Nilai Perusahaan Pada Perusahaan Manufaktur. E-Jurnal Manajemen Unud, Vol.5, No.3, 2016: 1572-1598. ISSN : 2302-8912.

Nachrowi, N. Djalal dan Hardius Usman. 2006. Pendekatan Populer dan Praktis Ekonometrika untuk Analisis Ekonomi dan Keuangan. Jakarta: LPFE Universitas Indonesia.

Riyanto, Bambang. 2010. Dasar-Dasar Pembelanjaan Perusahaan. Edisi Keempat. BPFE-Yogyakarta.

Saleh, D. S. (2018). Pengaruh Operating Capacity, Arus Kas Operasi dan Biaya Variabel terhadap Financial Distress pada Perusahaan Manufaktur Subsektor Textil dan Garment yang Terdaftar di Bursa Efek Indonesia (Bei) Tahun 20092016. Eqien: Jurnal Ekonomi dan Bisnis, 5(1), 34-49.

Shochrul R, A., Sari, D. W., Setianto, R.H., \& Primanti, M. 2011. Cara Cerdas Menguasi Eviews. Jakarta: Salemba Empat.

Sjahrial, D., dan Purba, D. 2013. Analisis Laporan Keuangan. Jakarta: Mitra Wacana Medi.

Sudana, I.M. 2011. Manajemen Keuangan Perusahaan Teori \& Praktik. Jakarta : Erlangga.

Surtikanti, S., \& Saleh, D. S. (2018, November). Economic Value Added. In International Conference on Business, Economic, Social Science and Humanities (ICOBEST 2018). Atlantis Press. 
Sugiyono. 2009. Metode Penelitian Pendidikan, Pendekatan Kuantitatiff, Pendekatan Kualitatif, dan R\&D. Bandung: Alfabeta.

Sugiyono. 2017. Metode Penelitian Kuantitatiff, Kualitatif, dan R\&D. Bandung: Alfabeta.

Sujarweni, V. W. 2014. Metodologi Penelitian. Yogyakarta: Pustaka Baru Press.

Surtikanti, S., \& Saleh, D. S. (2018, November). Economic Value Added. In International Conference on Business, Economic, Social Science and Humanities (ICOBEST 2018). Atlantis Press.

Saleh, D. S. (2018). Pengaruh Operating Capacity, Arus Kas Operasi dan Biaya Variabel terhadap Financial Distress pada Perusahaan Manufaktur Subsektor Textil dan Garment yang Terdaftar di Bursa Efek Indonesia (Bei) Tahun 20092016. Eqien: Jurnal Ekonomi dan Bisnis, $5(1), 34-49$.

Syarinah Sianipar. 2017. Pengaruh Struktur Modal dan Profitabilitas Terhadap Nilai Perusahaan pada Sektor Makanan dan Minuman. Jurnal FISIP Volume 4 No 1. Jurusan Ilmu Administrasi Fakultas Ilmu Sosial dan Ilmu Politik Universitas Riau.

Tiewy Agistine Hidayat. 2017. Pengaruh Struktur Modal, Kebijakan Deviden, Profitabilitas Terhadap Nilai Perusahaan Pada Perusahaan Manufaktur yang Terdaftar di Bursa Efek Indonesia tahun 2011-2015. Jurnal Ilmu dan Riset Manajemen Volume 6. Nomor 5, Mei 2017 ISSN: 2461-0593.Sekolah Tinggi Ilmu Ekonomi Indonesia (STIESIA) Surabaya.

Umar, Husein. 2008. Metode Penelitian Untuk Skripsi Dan Tesis Bisnis. Edisi Kedua. Jakarta: PT Raja Grafindo Persada.

Widarjono, Agus. 2007. Ekonometrika: Teori dan Aplikasi untuk Ekonomi dan Bisnis, Edisi Kedua. Yogyakarta: Ekonisia FE Universitas Islam Indonesia.

Zainal Abidin, Mein W. S \& M. Ziyad. 2014. Pengaruh Struktur Modal, Kebijakan Dividen, dan Size Terhadap Nilai Perusahaan Pada Perusahaan Properti Di Bursa Efek Indonesia. Jurnal Wawasan Manajemen, Vol. 2, Nomor 3. 